ascribed to the era of 58 B.C., ${ }^{1}$ and there is no reason why the Panjtar inscription from the same country, written in the same characters and language and dated in the same style, should not also be ascribed to the same era. We find, therefore, that while the Indo-Parthian Gondophernes was reigning in the Yusufzai district in A.D. 46, an unknown Kushan was reigning there in A.D. 65. This unknown Kushan can scarcely be a successor of Vāsudeva, since Vāsudeva's rule never extended to these regions. He must be one of the Kadphises group. His name, if it was ever entered on the stone, must have been one of the shortest. But it is at least very doubtful whether his name was introduced there at all. In that case (and it seems the most probable), the inscription can be ascribed with much likelihood to the time of the Nameless King. The absence of the imperial titles Devaputra and Rājatirāj $j a$ from the record bears out this supposition.

If, then, the above chain of reasoning is admitted as probable, it will follow: (1) that the conquest of Kabul by Kozoulo Kadphises, and his death, occurred in the interval of nineteen years between A.D. 46 and 65 ; (2) that the Nameless King was governor of Kabul and co-regent with Wema Kadphises in the regions south of the Hindu Kush from the commencement of the latter's reign; (3) (but more doubtfully) that Wema Kadphises had not yet entered on the conquest of India in A.D. 65 . This last inference, although more doubtful in itself, is probable on other grounds.

\title{
J. KENNEDY.
}

\section{Fresh Light on Kaxishika}

There were two propositions in the "Secret of Kanishka" (JRAS. 1912, pp. 685 ff. and $981 \mathrm{ff}$.) which I could not prove at the time except indirectly and by inference. I showed (1) that Wema Kadphises' conquest of the

1 See JRAS.; 1905, p. 229 ff. 
Panjāb must have been a reconquest of the country, and (2) that a cursive Greek script must have been in use among the traders from the Persian Gulf. But direct evidence on both these points was wanting. I am now able to furnish it.

1. We saw (JRAS. 1912, p. 683) that a Kushan king existed in the North-West of India at a time when the Yavanas were still masters of Käbul, that is, down to the beginning of the Christian era. We also saw that this kingdom disappeared under the assaults of the IndoParthians and Northern Kshatrapas, and that it was re-established by Wema Kadphises in the third quarter of the first century A.D. The Hou Han Shu or "History of the Later Han " is our authority for this second conquest. In the translation which I used the passage runs thus: "Son fils Yen-kao-tchen (Oêmo Kadphisês) devint roi à sa place; $\grave{a}$ son tour, il conquit le T'ien-tchou (Inde)"the India in question being the Panjāb. Learning, however, that the words I have italicized gave a faulty impression of the meaning of the original, I betook myself to a very competent Sinologist, who has furnished me with the following transliteration and literal translation. ${ }^{1}$ The passage is in the Hou Han Shu, ch. 88 , fol. $8 \mathrm{r}^{\circ}$, col. $2 ;^{2}$ the words are these :-

\begin{tabular}{cccc}
$(1)$ & $(2)$ & $(3)$ & $(4)$ \\
tai & wei & wang. & $F u$ \\
In-his-place & was & king. & Again \\
$(5)$ & & $(6 \& 7)$ \\
mieh & \multicolumn{3}{c}{ Tien-chu. } \\
extinguished & \multicolumn{3}{c}{ T'ien-chu (= India). }
\end{tabular}

1 Professor Sten Konow was the first to point out the correct rendering of this passage, and has published it recently in his paper on the "Kushanas" at the Historical Congress of London. My thanks are due to Mr. Giles, of the British Museum, for his assistance in the matter. I may add that this paper was written some time before the delivery of Professor Konow's lecture at the Congress.

2 The reference is to the standard edition of the Dynastic Histories. 
We may therefore paraphrase the sentence thus: " $\mathrm{He}$ (Wema Kadphises) succeeded him (Kozoulo Kadphises) on the throne, and subjugated India again."

The capital word here is fu, "again." It can only mean that Wema Kadphises' conquest of the Panjāb was the second time the Kushans had taken it. It implies (1) that the Kushans had formerly conquered North-West India, (2) that they had lost it, and (3) that Wema Kadphises restored their dominion over it. Now the five Yue-che principalities, including the Kushan, of the Hindu Kush and the Pamirs date from c. 100 B.c. or 90 B.c. ${ }^{1}$ We have therefore an anterior time-limit for the first Kushan kingdom. Fan Ye, the author of the Hou Han Shu or "History of the Later Han", furnishes us with a posterior limit, for he tells us that he purposely omits all mention of events which happened before A.D. 25. We must therefore admit, on the authority of the Hou Han Shu, the existence of a Kushan kingdom in NorthWestern India, which arose, flourished, and fell into decay between 100 or 90 B.C. and A.D. 25 - a fact which is demonstrable in another way. We also know that this Kushan kingdom was ruled by Buddhist princes, whose officials first introduced Buddhism to the Chinese. ${ }^{3}$

We have therefore two Kushan conquests of the Panjāb, the one dating from the first half, or the middle, of the first century B.C., the second from the later half of the first century A.D. The first conquest was transient, or, more correctly speaking, the Kushan kingdom was temporarily submerged; the second kingdom was stable, and lasted without a break to the time of the Guptas. And we hear of only two Kushan conquerors. The "History of the Later Han" has preserved the memory of Wema Kadphises, who (to judge from his coins) was a worshipper of Siva. During his reign the Buddhist

1 JRAS, 1912, p. 669.

3 JRAS. 1913, p. 369.

2 T"oung-pao, sér. Ir, vol.viii, No. 2, p. 168. 
propaganda in China ceased, and Indian tradition takes no note of him. Kanishka, on the other hand, was famed throughout the Buddhist world; he overthrew Magadha, and subdued, if all stories be true, every region except the north; his kingdom extended to Benares and Ghazipur. Tradition, inscriptions, and coins combine to magnify his name. If he was not the first Kushan to conquer India, where shall we find room for him, and to whom shall we assign the glory of the earlier exploit? We must postulate an unknown hero, a great conqueror, a zealous Buddhist, who plays the part of Kanishka, his very counterpart and second self; a hero, moreover, who has disappeared and left no trace of his separate existence. I do not think we can expect such self-abnegation even from a Buddhist.

2. I have shown that Kanishka borrowed his Greek alphabet from the traders of the Persian Gulf; and I suggested that his cursive mercantile script came from the same quarter. ${ }^{1}$ Kanishka uses uncial Greek characters only on such of his coins which have legends in the Greek language BACI $E Y C$ BACIAEWN KANHPKOV, together with the Greek gods Hephaistos, Helios, and Selene, as well as on those which bear the name and figure of the Elamite Nanaia. On his other coins he uses cursive Greek, while Huvishka and Văsudeva use the cursive Greek alone. These coins were all struck (as I maintain with Dr. Fleet) within, roughly speaking, the century 60 B.C.-A.D. 40.

Now, I find that a cursive Greek alphabet was used by two contemporaneous kings of Elymais, or Elam, the country of the goddess Nanaia, who figures so largely on these Kushan coins. The history of Elam during this period is exceedingly obscure; so far as it is known it has been recovered chiefly from coins, and within the last thirty or forty years. The kings of Elam used 1 JRAS. 1912, p. 1009. 
Aramaic legends. As a rule they used nothing else. But two kings, Orodes I and Phraates I, struck coins with Greek legends, and these legends are in cursive Greek. Moreover, like the coins of Kanishka, the coins are unilingual. They have no accompanying Aramaic legend. More than two hundred of the coins of these two kings have been found at Susa and Shiraz. Orodes I succeeded the last king of the Kamnascires family, whose latest date is 82 B.C., or possibly 72 B.c. Phraates I comes between him and the end of the century. Whether these princes belonged to the line of the Arsacids, is a matter of dispute. They have Arsacid names; but they claim on their coins some sort of connexion with the Kamnascires who preceded them, and they take the modest title of "king", and not "king of kings". Moreover, Elam remained semiindependent to a much later date. ${ }^{1}$

Allotte de la Fuye, from whom I have taken these details, gives the following description of the Greek legends on these Elamite coins: "Elles sont écrites en caractères cursifs, plus ou moins barbares, dont quelquesuns rappellent les formes araméennes; les légendes sont directes ou rétrogrades, les lettres y occupent les positions les plus diverses, tournées tantôt vers le centre, tantôt vers $\mathrm{l}_{\mathrm{e}}$ periphérie de la monnaie, quelquefois couchées; notons en particulier les formes qu'affectent l'epsillon $\beta, B, \beta$.

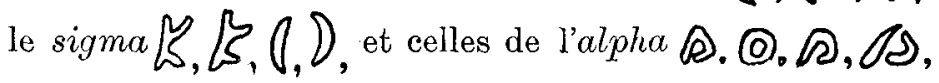
dont quelques-unes sont très analogues à un omicron." 2

A comparison of the Kushan and the Elamite cursive scripts would be of the greatest interest, were it possible. Unfortunately the Elamite coins have nothing beyond the name and the word $B A C I \triangle E Y C$, and this word is wanting

1 For the contemporary history of Elymais and Persis see v. Gutschmid, Geschichte Irans, pp. $156 \mathrm{ff}$, and Allotte de la Fuye, Monnaies de. l'Élymä̈de, pp. 42 ff. ; also Head, Historia Numorum, s.v. Persis.

2 Op. cit., p. 29. 
on the corresponding Kushan coins, which substitute the title PAO or PAONANO PAO. ${ }^{1}$ The Kushan lettering appears to me better cut and less barbaric than the Elamite-a fact which is not strange, since the Greek population in Elam and Persis was at all times very small. But the close connexion of the Kanishka Greek alphabet with that in use in Elymais and Characene is incontrovertible. Equally noteworthy is the preference of these Elamites and Kushans for Greek instead of the popular Aramaic and Prakrit. I have been asked why Kanishka put Greek legends, and Greek legends only, on his copper coins, as well as on his gold. I can only answer that his Elamite contemporaries did the same.

\section{J. KENNEDY.}

\section{AjIvika}

In his admirable treatise upon the Ajivikas in Hastings' Encyclopadia of Religion and Ethics, i, p. 259 seq., Dr. Hoernle writes as follows: "On the exact signification of the name 'Ájivika' we have no information." However, he thinks it probable that the name was not originally taken up by the followers of the heresiarch Gosāla themselves, but was from the beginning a nickname given to them by their opponents and meant to denote them as practising ascetic rules only as a means of gaining a livelihood $(\bar{a} j \bar{\imath} v a)$. So $\ddot{a} j \bar{\imath} v i k a$ would mean "professional" or something like that.

It cannot be denied that this seems to be the most probable explanation of this rather obscure word. Nor do I pretend to be in a position to offer a better one. But

1 I have compared, with Mr. Allan's assistance, some of the coins of Phraates in the British Museum with the Kushan. The only distinctive letters I could find common to both were the alpha and epsilon. The Kushan letters appeared to me sharper and more angular; more italianated, as our writing masters would have said. The epsilon in particular sometimes resembled a cuneiform wedge, a form which is occasionally found in Egyptian graffiti. 